\title{
Article \\ The Experimental Study of Innovative Methods Regarding the Removal of Sm(III)
}

\author{
Olga Leonidovna Lobacheva * and Natalia Vladimirovna Dzhevaga
}

check for updates

Citation: Lobacheva, O.L.;

Dzhevaga, N.V. The Experimental

Study of Innovative Methods

Regarding the Removal of Sm(III).

Appl. Sci. 2021, 11, 7726. https://

doi.org/10.3390/app11167726

Academic Editors: Anthony William

Coleman and Francesco Enrichi

Received: 18 June 2021

Accepted: 17 August 2021

Published: 22 August 2021

Publisher's Note: MDPI stays neutral with regard to jurisdictional claims in published maps and institutional affiliations.

Copyright: (c) 2021 by the authors. Licensee MDPI, Basel, Switzerland. This article is an open access article distributed under the terms and conditions of the Creative Commons Attribution (CC BY) license (https:// creativecommons.org/licenses/by/ $4.0 /)$.
General Chemistry Department, Saint Petersburg Mining University, 199106 Saint-Petersburg, Russia; Dzhevaga331@mail.ru

* Correspondence: Olga-59@yandex.ru; Tel.: +7-9043304994

Abstract: The modern development of the construction materials sector determines the use of rare earth metals (REM) for various purposes. In particular, REM are added as basic alloying elements into magnesium alloys to increase alloy durability and strength. The complex systematic study of structural components and REM interaction are the basis for the phase state monitoring of multicomponent oxide polyfunctional materials. In addition, on the preparatory stage, layers with specified construction material coatings are formed. The paper presents experimental and theoretical results of studies of adsorptive bubble methods in the systems containing Samarium cations and surfactants, namely sodium dodecyl sulphate (NaDS). To identify the process mechanisms and prediction of optimal conditions of metal cations' removal and separation by extraction, flotation, and ion flotation methods, one should know the $\mathrm{pH}$ of metal hydroxo-complexes and $\mathrm{pH}$ of the hydrate formation. The possibility of lanthanide ions' removal (by the example of Samarium ions) by the solvent sublation method with $\mathrm{NaDS}$ as a collector and isooctyl alcohol as an extractant was studied. From the obtained experimental data, it was clear that the $\mathrm{Sm}^{3+}$ removal in acidic mediums is practically non-existent. The results obtained in this paper are topical in the production of electrode coating components, welding fluxes, sorbents for nuclear wastewater burial, wastewater treatment, highly porous heat-insulating and fire-resistant materials, cement, and concrete with improved frost resistance.

Keywords: solvent sublation; ion flotation; extraction; rare earth metals; construction materials; recovery

\section{Introduction}

Russia has no less than $20 \%$ of world's REE (rare earth elements) reserves but the volume of the extraction of raw materials is only $2 \%$ of the world's extraction volume $[1,2]$. The production of products with REM in Russia is less than 1\% of world's production volume [3-5].

REE is used in various industry fields (Figure 1) such as in: magnet production (samarium, neodymium, and dysprosium); luminophores (yttrium, europium, and terbium); capacitors (lanthanum); optical glass (lanthanum and cerium); ceramics (yttrium), etc.

Current Russian and foreign REM production techniques are rated for small-scale production. A special feature of available Russian raw material sources is the REM low content and complex chemicomineralogical composition. On the achieved technological level, processing of this type of raw materials is unprofitable [6-8]. The complex systematic study of the interaction of structural components in nitrate systems of lanthanides of the cerium family and the representatives of the $\mathrm{Li}, \mathrm{Na}$, and $\mathrm{K}$ chemical group established the formation of the representative class of Ln alkali coordination nitrates [9-11]. The findings form the basis for revealing and controlling the phase state of processing facilities in preparatory stages when forming construction material coating layers, as well as the determination of process and functional dependences for changing the composite material properties [12-14]. In addition, the studies conducted at Kola Peninsula, one of the most 
developed Arctic regions in Russia, are of interest. Ores mined at the existing deposits may be used for the production of up to 30 different concentrates. Materials produced from local mineral deposits include metallic nickel; cobal; copper; titanium; niobium; rare earth metals; steel; sealants; electrode coating components and welding fluxes; sorbents for burial of nuclear wastes and wastewaters containing heavy non-ferrous metals and other pollutants; highly porous heat-insulating and fire-resistant materials; cement; and concrete with improved frost resistance $[15,16]$.

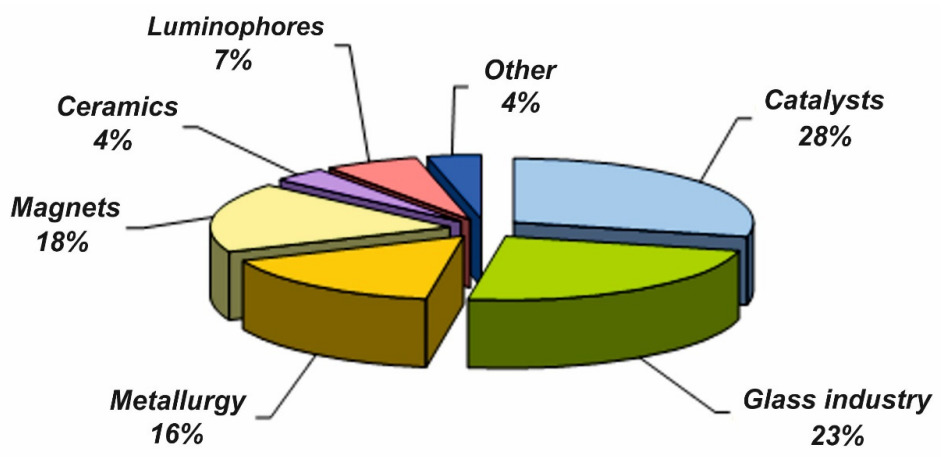

Figure 1. World's consumption pattern of REM [3].

The three methods of lanthanide cations removal are studied, namely ion flotation, solvent sublation, and extraction.

The work objective is an experimental and thermodynamic study of the possibility of selective REE removal (by the example of $\mathrm{Sm}^{+3}$ ) by adsorptive bubble methods.

\section{Materials and methods}

\subsection{Ion Flotation}

According to data by foreign researchers, an increase of effectiveness in current technologies at the expense of accompanying extraction of valuable components from production wastes [7,8] is possible when using ion flotation methods [17] in the mining industry. The consequence of the decrease of REE toxicity and risk of damaging the environment is presumed. In papers [5-7], the ion flotation method is proposed for REE removal from apatite sulphuric acid processing products by different anion surfactants. At the production scale, the ion flotation process permits the preventing of sediment formation, REE loss, and usage of expensive extractants.

In particular, the ion flotation method is commercially used for the removal of nonferrous, rare-earth, and radioactive metal cations from industrial and residential wastewaters [11]. In addition, when using different types of flocculants and coagulants, wastewater treatment for petroleum and oil impurities by the ion flotation method is possible [12]. When reaching certain conditions, the ion flotation process provides almost a $100 \%$ recovery of precious metals from solutions [18,19].

This work studies the distribution of $\mathrm{Sm}^{+3}$ ions in "water phase" - "froth phase" systems formed by standardized test solutions containing $\mathrm{Sm}^{3+}$ ions and a surfactantsodium dodecyl sulphate. A diagram of the lanthanide flotation machine is shown in Figure 2. NaDS is used as one of the most common and well-studied surfactants. (CCM) is $8 \times 10^{-3} \mathrm{~mol} \cdot \mathrm{kg}^{-1}$ at $20^{\circ} \mathrm{C}$ [1]. It is evident that this permits using solutions with a concentration below this value. 


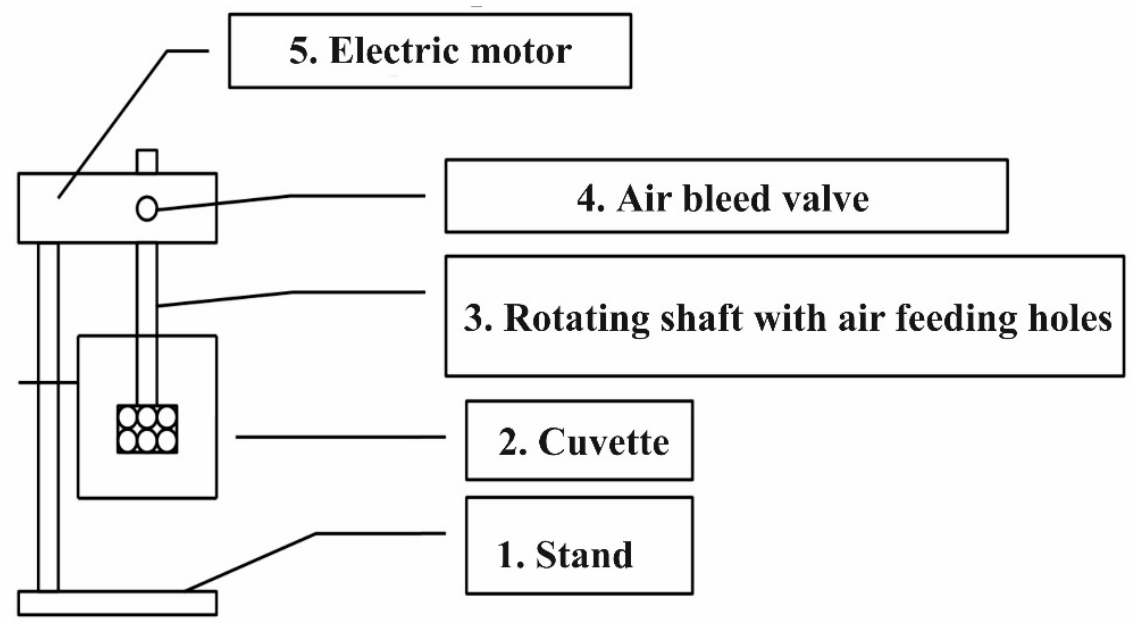

Figure 2. A diagram of the В-ФЛ137 flotation machine.

For reasons of the surfactant economy and achievement of the concentration effect, it is reasonable to use a minimum amount of collector, close to its stoichiometric consumption in accordance with the reaction:

$$
\mathrm{Me}^{3+}+3 \mathrm{C}_{12} \mathrm{H}_{25} \mathrm{OSO}_{3} \mathrm{Na}=\mathrm{Me}\left[\mathrm{C}_{12} \mathrm{H}_{25} \mathrm{OSO}_{3}\right]_{3}+3 \mathrm{Na}^{+}
$$

The chemically pure grade samarium nitrate hexahydrate was used. The initial concentration of samarium nitrate solution was $0.001 \mathrm{~mol} / \mathrm{L}$ and the sodium dodecyl sulphate concentration was three times higher: $0.003 \mathrm{~mol} \cdot \mathrm{L}^{-1}$ or $0.864 \mathrm{~g} / \mathrm{L}\left(\mathrm{DS}^{-}\right.$, dodecyl sulphate ion). The $\mathrm{pH}$ value of the solution was monitored by the "Anion 7010" ion meter with a glass electrode [18]. To find out the $\mathrm{pH}$ value of the solution, the nitric acid solution or sodium hydroxide solution were used.

The ion flotation process was conducted on the flotation machine (Figure 2) [19]. In total, $200 \mathrm{~mL}$ of samarium nitrate solution with the concentration of $0.001 \mathrm{~mol} / \mathrm{L}$ and dry NaDS were added to the cuvette. The process continued for no more than $5 \mathrm{~min}$. The picked-out froth was broken by $5 \mathrm{~mL}$ sulphuric acid solution with the concentration of $1 \mathrm{~mol} \cdot \mathrm{L}^{-1}$. The obtained solution (froth pulp) and the solution remained in the cuvette after flotation (chamber residue) and were analyzed for REE content by using the method in [20] and for dodecyl sulphate ion content by the potentiometer method [21,22].

\subsection{Solvent Sublation}

Solvent sublation is a method of surface separation combining the flotation of ions or molecules and a method of liquid extraction. The organic phase (in-out case that is isooctyl alcohol) was above the aqueous phase [17]. The process was implemented with small gas consumption. The method was used for wastewater treatment from organic impurities and for quantitative determination of trace metals and surfactants [23-25].

The feature of solvent sublation regarding the possibility of the concentration of multiple metal ions in a small volume of organic solvent shows the potential of this method for wastewater treatment containing metal ions for their subsequent recovery. It should be noted that currently available data regarding the organic phase nature, which are very limited [26,27], indicate that the organic phase ("trap") should have some polarity and should comply with basic requirements for an organic phase in solvent sublation including: being less dense than water; minimum water solubility; and maximum capacity of sublate accumulation. Nowadays, many authors of conducted studies showed that during solvent sublation, the substance distribution is determined by its ability to adsorb on bubble walls, passing through the solution, and it does not depend on the phase volume relationship. Thereby, the sublate adsorption process is the determining factor of the process. 
Compared to the foam separation method, the process of solvent sublation is poorly studied. Originally, solvent sublation was proposed for ion removal by the surfactant and afterwards the process was realized for dissolved substance removal based on their surface activity and sediment flotation $[19,28,29]$.

Additionally, there is a carrier agent for the colligand in solvent sublation surfactants. An important property of this method is its high selectivity. In the flotation method, most dissolved impurities go into the froth, while in solvent sublation, one can achieve such a separation, at which the substance partially goes into the organic phase and partially returns. It should be noted that with foam separation, water is also removed from the solution together with the isolated substance. First, this reduces the concentration ratio of the substance. Second, in the foam separation method, water removal results in rapid floating solution consumption and in the end, prevents from making a total curve during the experiment with one initial solution. In solvent sublation, this is not the case, as water always returns to the aqueous phase. Despite all advantages, the solvent sublation method has disadvantages: (1) it is not always possible to select a solvent that could dissolve the formed sublate and (2) both the formation of aqueous emulsion in the organic phase is possible and the contamination of this organic phase by undesirable ingredients from the aqueous solution is possible [1].

In the solvent sublation process, a glass column was used [1]. In total, $100 \mathrm{~mL}$ of $\mathrm{Sm}\left(\mathrm{NO}_{3}\right)_{3}$ (chemically pure grade samarium nitrate hexahydrate) and $5 \mathrm{~mL}$ of 2-octanol were added into the column. Nitrogen was fed through the glass filter at the base of the column. The process time was $2 \mathrm{~h}$.

\subsection{Extraction}

Extraction processes are currently the basic practice in REM separation. In industry practice, tributyl phosphate, DEHPA, carboxylic acids, and ammonium base salts are mainly used for lanthanide separation [30].

Separation is based on the regular change in distribution coefficient (D) values in the lanthanide series (Figure 3).

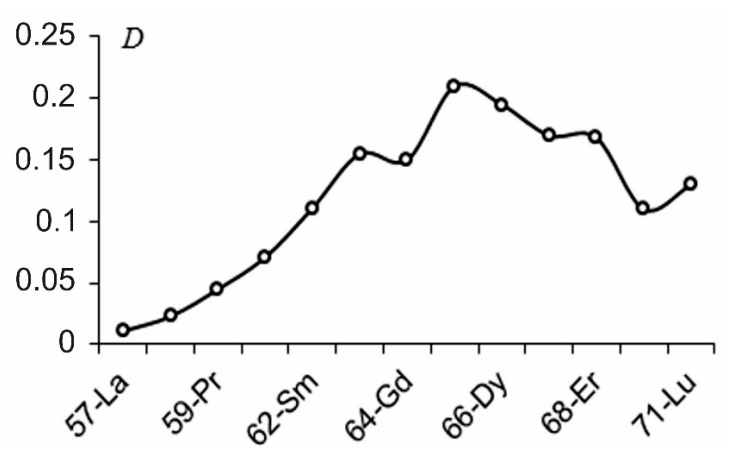

Figure 3. REM distribution coefficient (D) when extracting by TBP from nitrate weak-acid solutions [31].

It was discovered that extraction removal was conducted at the expense of samarium (III) cations and $\mathrm{Sm}(\mathrm{OH})^{2+}$ moving into the organic phase. A shortcoming of this method is that the process does not flow at $\mathrm{pH}<4$, though in practice valuable components need to be recovered from acid mediums. Thus, the extraction process in solutions containing samarium ions with $\mathrm{NaDS}$ at $\mathrm{pH}=3.0-6.0$ was studied. Dry sodium dodecyl sulphate and chemically pure grade samarium nitrate hexahydrate were used. The studied metal cation solution in the volume of $200 \mathrm{~mL}$ was placed into the $250 \mathrm{~mL}$ beaker. Next, dry sodium dodecyl sulphate was added up to the concentration of $0.003 \mathrm{M}$.

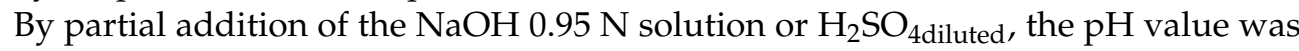
adjusted to the required value. Then, $5 \mathrm{~mL}$ of isooctyl alcohol was added. The obtained solution was stirred by the agitator ES-8300 D at approximately 700 RPM. 


\section{Results and Discussion}

\subsection{Results of the Ion Flotation Method}

The results of the ion flotation study of the solutions containing $\mathrm{Sm}^{+3}$ иDS ${ }^{-}$are shown in Table 1.

Table 1. The results of the experimental study of samarium ions' distribution between aqueous and organic phases.

\begin{tabular}{|c|c|c|c|}
\hline $\mathrm{pH}$ & $\begin{array}{c}{\left[\mathrm{Sm}^{3+}\right] \mathrm{aq} \cdot 10^{4}} \\
\mathrm{~mol} / \mathrm{L}\end{array}$ & $\begin{array}{c}{\left[\mathrm{Sm}^{3+}\right] \text { org } \cdot 10^{3}} \\
\mathrm{~mol} / \mathrm{L}\end{array}$ & $\mathbf{K}_{\mathbf{p}}$ \\
\hline 1.8 & 5.64 & 1.79 & 3.2 \\
\hline 3.0 & 2.36 & 2.15 & 9.1 \\
\hline 3.5 & 1.39 & 2.24 & 16.2 \\
\hline 4.0 & 1.30 & 2.31 & 17.7 \\
\hline 4.9 & 1.71 & 2.00 & 11.7 \\
\hline 5.4 & 1.83 & 2.18 & 11.9 \\
\hline 6.0 & 1.31 & 2.13 & 16.2 \\
\hline 6.7 & 0.23 & 3.03 & 130.4 \\
\hline 6.9 & 0.25 & 3.27 & 128.9 \\
\hline 7.5 & 0.28 & 3.56 & 128.6 \\
\hline 7.9 & 0.30 & 3.91 & 128.7 \\
\hline 9.5 & 0.30 & 3.91 & 129.5 \\
\hline
\end{tabular}

From the obtained experimental data, it is evident that the $\mathrm{Sm}^{3+}$ removal in acidic mediums is practically non-existent. With the increase of the $\mathrm{pH}$ value from 3.5 to 6.0 , the distribution coefficient was approximately 16 . Not surprisingly, in this $\mathrm{pH}$ range, neutral and basic dodecyl sulphates of samarium $\mathrm{Sm}\left(\mathrm{C}_{12} \mathrm{H}_{25} \mathrm{OSO}_{3}\right)_{3}$ иSm $(\mathrm{OH})\left(\mathrm{C}_{12} \mathrm{H}_{25} \mathrm{OSO}_{3}\right)_{2}$ floats. From the obtained experimental data, it is evident that at a $\mathrm{pH}$ exceeding 6.0, the distribution coefficient $\left(\mathrm{K}_{\mathrm{p}}\right)$ increases rapidly. This value is lower than that previously determined by us through the $\mathrm{pH}$ of the hydrate formation (Formula (3). On this basis, it may be considered that in the $\mathrm{pH}$ range satisfying the maximum removal, samarium floats mainly in the hydroxide form, with which $\mathrm{DS}^{-}$anions form hydrogen bonds with the admixture of neutral and basic dodecyl sulphate.

According to the literature data, in the process of the ion flotation of metal cations, the increase in removal ratio occurs in the $\mathrm{pH}$ range of the hydrate formation [29] and notable cations go into the froth in the form of hydroxides. It is assumed that ion flotation non-ferrous metals flow with the formation of their basic salts with anion surfactants. A hypothesis was put forward based on a thermodynamic analysis of ion-molecular equilibriums that cerium ( $3+$ ) is extracted at $\mathrm{pH}=5$ by oleic and naphthenic acid solutions in diluents in the form of basic oleates and naphthenates, and yttrium in the form of neutral salts [30]. To identify the process mechanisms and predictions of optimal conditions of metal cations removal and separation by extraction, flotation, and ion flotation methods, one should know the $\mathrm{pH}$ of metal hydroxo-complexes and $\mathrm{pH}$ of the hydrate formation that can be calculated based on the Gibbs energies of hydroxo-complexes and metal hydroxides formation. The $\mathrm{pH}$ value of the $\mathrm{Sm}(\mathrm{OH})^{2+}$ hydroxo-complexes formation can be calculated based on the expression for instability constants:

$$
K_{n}=\frac{\left[\mathrm{Sm}^{3+}\right] \cdot a_{\mathrm{OH}^{-}} \cdot \gamma_{ \pm}}{\left[\mathrm{Sm}(\mathrm{OH})^{2+}\right]}
$$


The $\mathrm{pH}$ value of hydrate formation is calculated by the formula:

$$
\mathrm{pH}_{\text {hydr }}=14+13\left(\lg L-\lg C-\lg \gamma_{ \pm}\right)
$$

where $L$ is the product of hydroxide solubility; $C$ is the samarium cation concentration; and $\gamma_{ \pm}$is the salt average ion activity coefficient.

Although the Gibbs energy value for $\mathrm{Sm}(\mathrm{OH})_{3}$ formation is $-1281.56 \pm 3.77 \mathrm{~kJ} / \mathrm{mol}$, in [32,33], this value is missing. The Gibbs energy value of $\mathrm{Sm}(\mathrm{OH})^{2+}$ hydrate formation is $-859.95 \mathrm{~kJ} / \mathrm{mol}$, available in [32], which disagrees with the value of $-848.10 \pm 3.35 \mathrm{~kJ} / \mathrm{mol}$ as specified in [33]. Due to the poor accuracy of values available in the literature data, the $\mathrm{pH}$ evaluation of complex formation and hydrate formation by the conductometric titration method was attempted with subsequent calculation of thermodynamic quantities.

Conductometric titration was carried out as follows: $10 \mathrm{~mL}$ aliquots of $\mathrm{Sm}(\mathrm{NO})_{3}$ solution with the concentration of $0.001 \mathrm{~mol} \cdot \mathrm{kg}^{-1}$, acidified by nitric acid down to $\mathrm{pH}=3$ (approximately), were titrated with $0.002 \mathrm{~N}$ solution of $\mathrm{NaOH}$. After the addition of each portion of 1-2 mL alkali solution, the solution was agitated until the establishment of the constant value of specific electrical conductivity, measured by the "Anion 4100" conductometer. At the same time, the $\mathrm{pH}$ value was measured by the "Anion 7010" ion meter. After the results, the titration curve was plotted as shown in Figure 4.

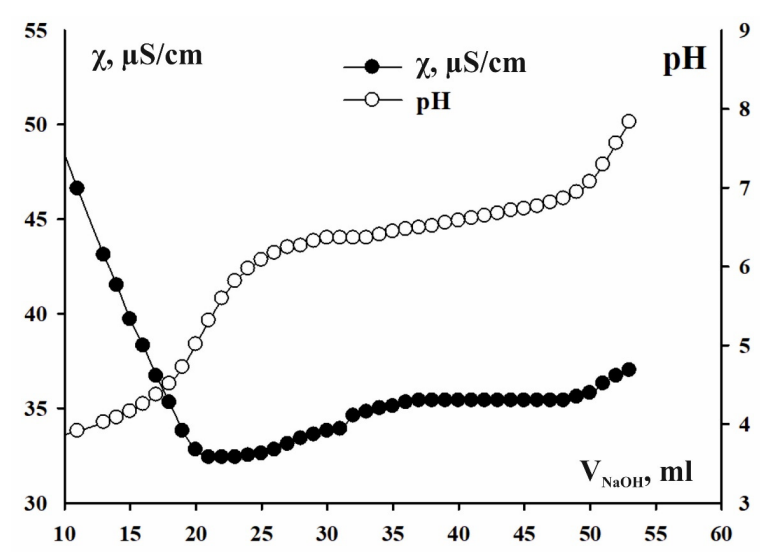

Figure 4. Specific electrical conductivity of the $\mathrm{Sm}(\mathrm{NO})_{3}$ solution and $\mathrm{pH}$ as a function of the $\mathrm{NaOH}$ solution volume in the course of conductometric titration.

By analyzing these relationships, we see that at $\mathrm{pH}=5.3$, there was a break in the curve of the specific electrical conductivity as a function of the added alkali with a transition to an almost horizontal part, which shows the added hydroxyl anions' fixation into poorly dissociated compounds. As the formation of hydroxides was not observed (optical density of solutions did not change), this part was responsible for the formation of hydroxocomplexes. By the quantity of milliequivalents of alkali used here, one can determine that the process flows until the formation of $\mathrm{Sm}(\mathrm{OH})^{2+}$ monohydroxo-complexes. The specified $\mathrm{pH}$ value was taken as the $\mathrm{pH}$ of the complex formation onset of $\mathrm{pH}_{\text {compl. }}$. Upon the completion of the complex formation, a near-linear growth of electrical conductivity with the addition of alkali was observed. At $\mathrm{pH}=6.49$, the growth of electrical conductivity stops. This part of the titration curve corresponds to the hydroxide sedimentation. The latter was observed visually and confirmed by an increase in the optical density of solutions.

The quantity of milliequivalents of alkali used here meets the following reaction: $\mathrm{Sm}(\mathrm{OH})^{2+}+\mathrm{OH}^{-}=\mathrm{Sm}(\mathrm{OH})_{3}$.

The $\mathrm{pH}$ value corresponding to the horizontal part of the titration curve was taken as the $\mathrm{pH}$ of hydrate formation $\mathrm{pH}_{\text {hydr }}$. Furthermore, on the titration curve, the near-linear growth of the specific electrical conductivity was observed because of the excess alkali.

The obtained calculated values are shown in Table 2. 
Table 2. Thermodynamic characteristics of Sm (3+) hydroxo compounds.

\begin{tabular}{ccccc}
\hline Compound & $\begin{array}{c}\boldsymbol{\Delta}_{f} G_{298}^{0} \\
\mathbf{k J} \cdot \mathbf{m o l}^{-\mathbf{1}}\end{array}$ & $\begin{array}{c}\boldsymbol{\Delta}_{\boldsymbol{s}} G_{298}^{0} \\
\left(\boldsymbol{\Delta}_{\mathbf{c o m p l}} \mathbf{G}_{298}^{0}\right), \\
\mathbf{k J} \cdot \mathbf{m o l}^{-\mathbf{1}}\end{array}$ & $\mathbf{L ~ ( K n )}$ & $\begin{array}{c}\text { pHhydr } \\
(\mathbf{p H c o m p l})\end{array}$ \\
\hline $\mathrm{Sm}(\mathrm{OH})_{3}$ & $-1280.16 \pm 3.63$ & $146.33 \pm 1.31$ & $(2.3 \pm 1.6) 10^{-26}$ & 6.49 \\
\hline $\mathrm{Sm}(\mathrm{OH})^{2+}$ & $-866.49 \pm 3.60$ & $-47.36 \pm 1.21$ & $(5.0 \pm 3.1) 10^{-9}$ & 5.31 \\
\hline
\end{tabular}

The obtained Gibbs energy value of the $\mathrm{Sm}(\mathrm{OH})_{3}$ formation agrees well with the database [32], in which the value of $-1281.56 \pm 3.77 \mathrm{~kJ} / \mathrm{mol}$ is specified (Table 2). The Gibbs energy value of samarium hydroxo-complex differs greatly from literature data, namely from $-848.10 \pm 3.35$ [32] and -859.95 [33]. We calculated the values of $\mathrm{Sm}(\mathrm{OH})^{2+}$ hydroxo-complex instability constants according to data from $[32,34]$ and calculated the values $8.4 \times 10^{-6}$ and $3.47 \times 10^{-7}$, corresponding to the $\mathrm{pH}$ of the complex formation onset by Formula (2), equal to 8.0 and 6.7. These values, however, were higher than the $\mathrm{pH}$ values of the hydrate formation that we determined and calculated based on $\Delta_{f} G^{0}{ }_{298}$ $\mathrm{Sm}(\mathrm{OH})_{3}$ from the reference book [34]. This is contradictory as the formation of hydroxocomplexes should carry at a $\mathrm{pH}$ below the $\mathrm{pH}$ of the hydrate formation and precede the hydroxide precipitation.

\subsection{Solvent Sublation Results}

The $\mathrm{Sm}^{+3}$ ions' content in the organic phase was determined from the concentration difference between the initial solution and aqueous phase [26].

The samarium ions' distribution coefficient during solvent sublation was calculated by the formula: $\mathrm{K}_{\mathrm{p}}=\mathrm{C}_{\mathrm{org}} / \mathrm{C}_{\mathrm{aq}}$ [1]. The results of the experimental study of the diluted aqueous solutions containing $\mathrm{Sm}\left(\mathrm{NO}_{3}\right)_{3}$ and a surfactant are shown in Tables 3 and 4 .

Table 3. $\mathrm{Sm}^{3+}$ concentration change in the aqueous phase during solvent sublation.

\begin{tabular}{cccccc}
\hline \multirow{2}{*}{ t, min. } & $\mathbf{p H}=\mathbf{5 . 1}$ & $\mathbf{p H}=\mathbf{6 . 1}$ & $\mathbf{p H}=\mathbf{6 . 9}$ & $\mathbf{p H}=\mathbf{8 . 0}$ & $\mathbf{p H}=\mathbf{9 . 9}$ \\
\cline { 2 - 6 } & \multicolumn{5}{c}{$\mathbf{C}_{\mathbf{a q}, \mathbf{m o l} / \mathbf{L}}\left(\mathbf{S m}^{+\mathbf{3}}\right.$ Initial Concentration) } \\
\hline 0 & 0.001 & 0.001 & 0.001 & 0.001 & 0.001 \\
5 & 7.81 & 7.39 & $\mathrm{C} \cdot 10^{4}, \mathrm{~mol} / \mathrm{L}$ \\
15 & 7.53 & 6.65 & 6.49 & 0.79 & 7.25 \\
30 & 7.06 & 6.48 & 4.30 & 0.61 & 5.83 \\
120 & 6.61 & 6.46 & 2.53 & 0.19 & 3.85 \\
& & 2.14 & 0.18 & 0.65 \\
\hline
\end{tabular}

Table 4. Recovery ratio $\alpha$ and distribution coefficient of samarium (III) (process duration was $120 \mathrm{~min}$ and $\left.\mathrm{C}_{0}=0.001 \mathrm{~mol} / \mathrm{L}\right)$.

\begin{tabular}{ccccc}
\hline $\mathbf{p H}$ & $\mathbf{C}_{\mathbf{o r g}} \cdot \mathbf{1 0}^{\mathbf{2}}$ & $\mathbf{C}_{\mathbf{a q}} \cdot \mathbf{1 0}^{\mathbf{4}}$ & $\mathbf{K}_{\mathbf{p}}$ & $\boldsymbol{\alpha} \mathbf{\%}$ \\
\hline 5.1 & 1.35 & 6.60 & 20.5 & 33.9 \\
6.1 & 1.41 & 6.30 & 21.9 & 35.4 \\
6.9 & 3.14 & 2.10 & 146.3 & 78.5 \\
8.0 & 3.92 & 0.17 & 2222.3 & 98.2 \\
9.9 & 3.74 & 0.65 & 576.9 & 93.5 \\
\hline
\end{tabular}

From the obtained data, it is evident that when the process time lies between 5 and $10 \mathrm{~min}$, the $\mathrm{Sm}^{+3}$ removal is more intense than by further floating. As a result, one can find an optimal solvent sublation process time in the REE nitrate solutions with the initial concentration of $0.001 \mathrm{~mol} / \mathrm{L}$. Depending on the solution $\mathrm{pH}$, it is $10 \mathrm{~min}$ and higher.

In time, the concentration of the studied REE ions asymptotically approaches some finite value, which is typical for the system moving into the stationary state, in which the equilibrium between the processes of lanthanide adsorption and desorption is established. 
At $\mathrm{pH}=5.0-6.0$, the process of solvent sublation removal moves into a stationary mode with high equilibrium concentrations. The maximum recovery ratio was approximately $25 \%$. In this $\mathrm{pH}$ range, the formation of monohydroxyo-complexes begins.

At $\mathrm{pH}=6.8-8.0$, the equilibrium concentration lowers and the recovery ratio increases, and an upward trend in the process rate was observed. The $K_{p}$ value and $\alpha$ reach maximum values. An explanation of the observed patterns is possible based on the consideration of diffusing particle forms at different $\mathrm{pH}$ values. In the aqueous solution at the $\mathrm{pH}$ range from 4.8 to 6.1 , the formation of lanthanide monohydroxo-complexes occurs; at $\mathrm{pH}=6.1-6.5$, dihydroxo-complexes are formed; and at the $\mathrm{pH}$ range from 6.5 to 7.5 , the formation of hydroxides occurs. At a $\mathrm{pH}$ exceeding 7.4, lanthanides in the aqueous phase are in the form of $\mathrm{Ln}(\mathrm{OH})_{2}\left(\mathrm{C}_{12} \mathrm{H}_{25} \mathrm{OSO}_{3}\right)$ organic complexes because otherwise the settling of the hydroxide sediment would occur, which was not observed. The limiting stage of the lanthanide and yttrium removal process is the diffusion of organic complexes and because of their large size, it flows slowly, the rate constant decreased by an order.

Thus, depending on the $\mathrm{pH}$ of the aqueous phase, the forms of dodecyl sulphate and samarium present in the aqueous phase change.

\subsection{Extraction Results}

In this paper, the possibility of using sodium dodecyl sulfate for the removal of Sm3+ by extraction with isooctyl alcohol is studied (Figure 5). The $0.001 \mathrm{M}$ standard test solutions of $\mathrm{Sm}^{3+}$ nitrates were used.

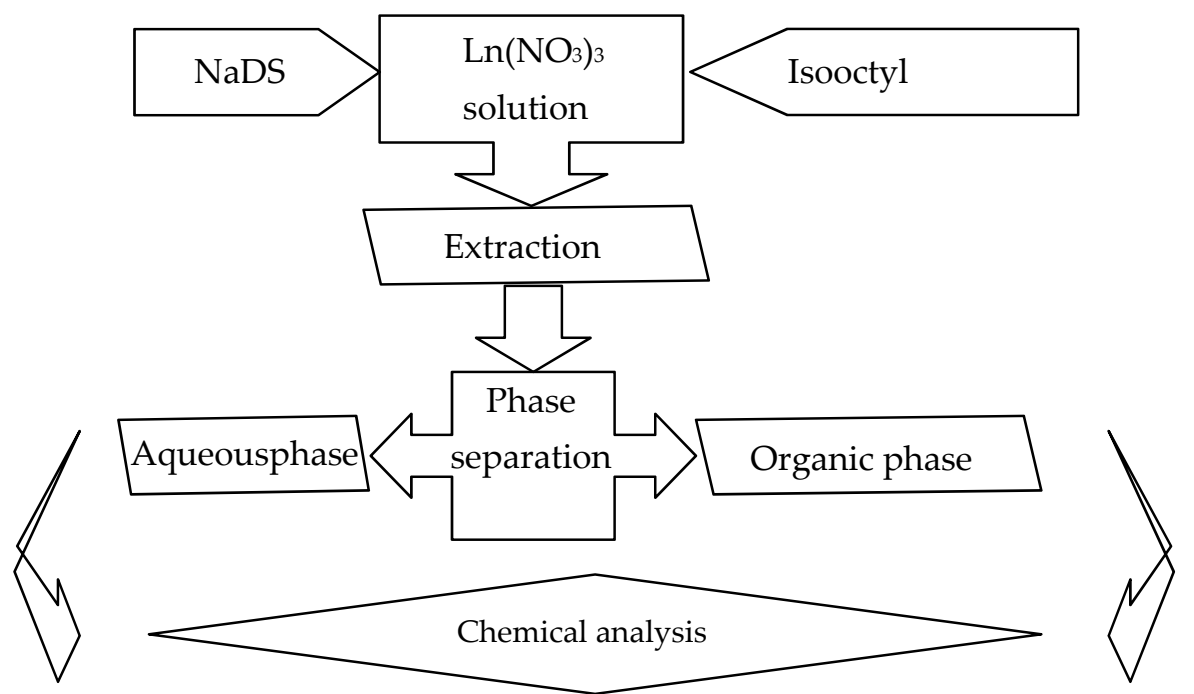

Figure 5. Scheme of the extraction process in the NaDS- $\mathrm{Sm}(\mathrm{NO}) 3-2$-octanol system.

The extraction was conducted for $30 \mathrm{~min}$. Aqueous and organic phases were separated in separate funnels of 0.25 or $0.5 \mathrm{~L}$ in capacity. Phase separation occurred over 3 to 5 days. The aqueous phase was analyzed by a photometric method for REE cations content. The form of salts extracted to the organic phase was determined by the IR spectroscopy method [35].

Sodium dodecyl sulphate (NaDS) is insoluble in non-polar solvents and, moreover, it is practically insoluble in alcohols. In this study, sodium dodecyl sulphate was added to the aqueous phase and isooctyl alcohol $\left(\mathrm{C}_{8} \mathrm{H}_{18} \mathrm{O}\right.$, 2-ethyl-1-hexanol) was used as an extractant.

During the experiment, it was discovered that NaDS goes to into the organic phase in the form of $\mathrm{Ln}\left(\mathrm{C}_{12} \mathrm{H}_{25} \mathrm{OSO}_{3}\right)_{3}$ solvates. Solubility can be explained by the polar group orientation towards the cation and solvate screening from the outer side by non-polar radicals. Apparently, alcohol molecules interact with REE cations as well, which confirms the stretching frequency $v_{\mathrm{O}-\mathrm{H}}$ shift and the lack of lanthanide dodecyl sulphate dissolution in non-polar solvents [35]. 
Certain experiments showed that rare earth elements are poorly extracted by alcohol in the absence of NaDS. When extracting holmium (III) cations at $\mathrm{pH}=6.0, \mathrm{~K}_{\text {distr }}$ was 4.46 , whereas in the presence of sodium dodecyl sulphate, it was 360 . Thus, isooctyl alcohol is an extractant, while NaDS acts as a carrier agent. Thus, the proposed extraction technique in the system, namely sodium dodecyl sulphate-lanthanide salt aqueous solution-isooctyl alcohol, significantly increases $\mathrm{K}_{\text {distr }}$ in the studied solutions.

Figure 6 shows the results of the experimental study of samarium (III) extraction. The initial concentration of REE was $0.001 \mathrm{M}$ and the sodium dodecyl sulphate concentration corresponded to the chemical reaction (1) stoichiometry and was $0.003 \mathrm{M}$. The organic phase volume $\left(\mathrm{V}_{\text {org }}\right)$ was $5 \mathrm{~mL}$ and aqueous phase volume $\left(\mathrm{V}_{\mathrm{aq}}\right)$ was $200 \mathrm{~mL}$, i.e., the ratio $\mathrm{V}_{\text {org }}: \mathrm{V}_{\mathrm{aq}}=1: 40$.

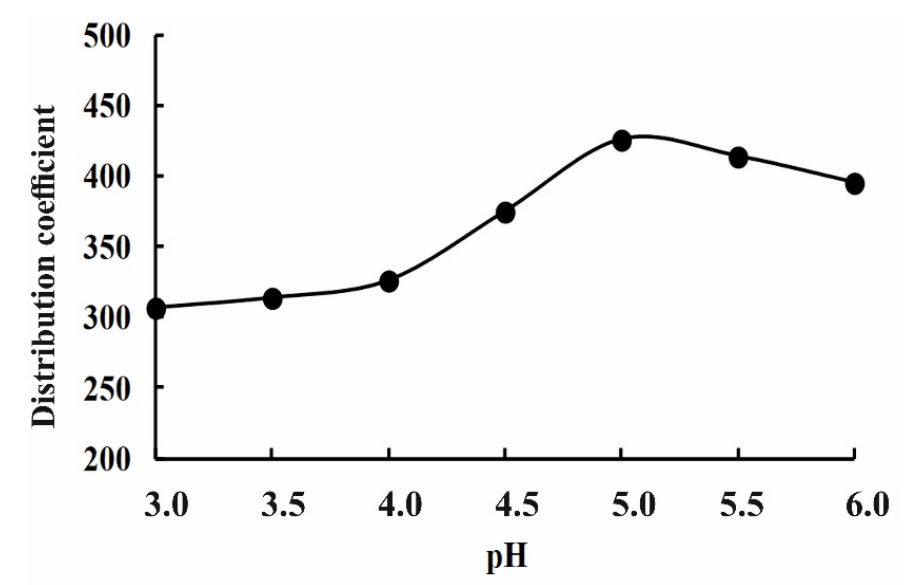

Figure 6. Samarium (III) cations' distribution coefficients as a function of solution $\mathrm{pH}$.

During the extraction, the dependence of $\mathrm{K}_{\text {distr }}$ from $\mathrm{pH}$ was weak and $\mathrm{Sm}^{3+}$ has the maximum $\mathrm{K}_{\text {distr }}$ at $\mathrm{pH}=5.0$. The distribution coefficient is significantly higher than when extracting by carboxylic acids. Removal from acidic mediums is possible.

Table 5 shows the results of the $\mathrm{Sm}^{3+}$ extraction with different initial concentrations at $\mathrm{pH}=4.0$.

Table 5. $\mathrm{Sm}^{3+}$ extraction with different initial concentrations at $\mathrm{pH}=4.0$.

\begin{tabular}{ccccc}
\hline $\mathbf{S m}^{3+}, \mathbf{m o l} / \mathbf{L}$ & $\begin{array}{c}{\left[\mathbf{S m}^{3+}\right]_{\text {aq }} \mathbf{1 0}^{3},} \\
\mathbf{m o l} / \mathbf{L}\end{array}$ & $\begin{array}{c}{\left[\mathbf{S m}^{3+}\right]_{\text {org, }}} \\
\mathbf{m o l} / \mathbf{L}\end{array}$ & $\mathbf{K}_{\text {distr }}$ & $\begin{array}{c}{[\mathbf{D S}]_{\mathbf{a q}} \mathbf{1 0}^{3},} \\
\mathbf{m o l} / \mathbf{L}\end{array}$ \\
\hline 0.1 & 16.48 & 4.02 & 243.6 & 0.57 \\
0.01 & 1.36 & 0.42 & 306.8 & 0.68 \\
0.001 & 0.13 & 0.04 & 326.1 & 0.76 \\
\hline
\end{tabular}

According to the extractant efficiency series, as shown in Table 6, one can come to the conclusion that sodium dodecyl sulphate has the most negative Gibbs energy of solvation $\Delta_{\mathrm{S}} \mathrm{G}^{\mathrm{O}}{ }_{298}$ and correspondingly the maximum $\mathrm{K}_{\text {distr }}$. In addition, it was discovered that when saturating isooctyl alcohol with sodium dodecyl sulphate, the spectrum remained unchanged, which demonstrates NaDS insolubility in alcohol [35].

Table 6. Gibbs energy of solvation when extracting Ce and Sm by different extractants [34].

\begin{tabular}{cccccc}
\hline $\begin{array}{c}\boldsymbol{\Delta}_{\mathbf{S}} \mathbf{G}^{\mathbf{0}}{ }_{298}, \\
\mathbf{k J} / \mathbf{m o l}\end{array}$ & TBP & TABAN & HNaft & Hol & NaDS \\
\hline $\mathrm{Ce}$ & $-4.1 \pm 0.2$ & $-7.9 \pm 0.5$ & $-27.6 \pm 0.4$ & $-33.1 \pm 0.4$ & - \\
$\mathrm{Sm}$ & - & - & $-22.2 \pm 0.5$ & $-35.8 \pm 0.5$ & $-70.0 \pm 0.5$ \\
\hline
\end{tabular}

Abbreviations: TBP, tributyl phosphate; TABAN, trialkylbenzyl ammonium nitrate; HNaft, naphthenic acid; and Hol, oleic acid. 


\section{Conclusions}

It is well known that rare earth elements are scattered in nature and do not manifest themselves in elementary states or even in the form of individual rare earth compounds.

They usually exist in rocks such as basalt, granite, gneiss, shale, and silicates in the form of mixed rare earth compounds forming various types of rare earth minerals. In general, most of these elements are mainly found in each type of rare earth mineral, but the distribution differs significantly between different minerals (Kanazawa and Kamitani, 2006). Therefore, to date, about 250 rare earth minerals have been found in more than 30 countries and regions. As a result of the low concentration, rare earth elements are formed as a by-product during the processing of various ores or are extracted from processed tailings or residues [36-41].

Considering the indispensable role of rare earth elements in the field of modern high technology, the efficient exploitation and utilization of rare earth resources is of great importance.

It should be noted that the removal of samarium ions from aqueous standard test solutions are by adsorption bubble methods, namely ion flotation, extraction, and solvent sublation.

In the processes under consideration, in our opinion, an interesting result is that the forms of the extracted components, namely $\mathrm{Sm}(\mathrm{OH})_{2}\left(\mathrm{C}_{12} \mathrm{H}_{25} \mathrm{OSO}_{3}\right)$ and $\mathrm{Sm}(\mathrm{OH})\left(\mathrm{C}_{12} \mathrm{H}_{25} \mathrm{OSO}_{3}\right)_{2}$, were found at different $\mathrm{pH}$ values of the researched solutions.

The experimental results obtained during the conducted studies show that in the process of ion flotation, the maximum extraction of $\mathrm{Sm}(+3)$ occurs at $\mathrm{pH}=6.7$. In the SS-max method, extraction can be achieved at $\mathrm{pH}=8.0$ and in the extraction method at $\mathrm{pH}=5.0$.

In addition, it was experimentally proven that $\mathrm{Sm}^{+3}$ distribution coefficients for ion flotation and solvent sublation with sodium dodecyl sulphate are significantly higher than for the extraction process.

Thus, we believe that, depending on the studied samples obtained during a certain treatment of minerals containing samarium cations, it is possible to use various adsorptionbubble methods for extracting REE.

The results obtained in this paper could be topical in the production of welding fluxes, sorbents for nuclear waste burial, wastewater treatment, highly porous heat-insulating and fire-resistant materials, cement, and concrete.

Author Contributions: Conceptualization, O.L.L.; methodology, O.L.L., N.V.D.; software, O.L.L., N.V.D.; validation, O.L.L., N.V.D.; formal analysis, O.L.L.; investigation, O.L.L., N.V.D.; investigation, O.L.L., N.V.D.; resources, O.L.L., N.V.D.; data curation, O.L.L.; writing—original draft preparation, O.L.L.; writing-review and editing, O.L.L.; visualization, O.L.L., N.V.D. Both authors have read and agreed to the published version of the manuscript.

Funding: This research was funded by State contract, grant number 14.740.11.0622 and "The APC was funded by Analytical departmental target program of the Ministry of Education and Science of the Russian Federation "Development of the scientific potential of higher education", grant number 2.1.1/973".

Institutional Review Board Statement: Not applicable.

Informed Consent Statement: Not applicable.

Conflicts of Interest: The authors declare no conflict of interest.

\section{References}

1. Lemlich, R. Adsorptive Bubble Separation Techniques; N.Y. Academic Press: New York, NY, USA, 1972; 344p.

2. Matveeva, V.; Danilov, A.; Pashkevich, M. Treatment of multi-tonnage manganese-containing waste water using vermiculite. J. Ecol. Eng. 2018, 19, 156-162. [CrossRef]

3. Kogan, B.I. Rare Metals. State and Prospects; Nauka: Moscow, Russia, 1978; 376p.

4. Hidayah, N.N.; Abidin, S.Z. The evolution of mineral processing in extraction of rare earth elements using liquid-liquid extraction: A review. Miner. Eng. 2018, 121, 146-157. [CrossRef] 
5. Goman, I.V.; Varlakova, E.A. Teaching communication skills in a foreign language to students of oil and gas specialization. Int. Multidiscip. Sci. GeoConf. Surv. Geol. Min. Ecol. Manag. SGEM 2019, 19, 295-300. [CrossRef]

6. Goman, I.V. Teaching writing skills in the foreign language to future petroleum engineers specializing in oil and gas development and operation. Int. Multidiscip. Sci. GeoConf. Surv. Geol. Min. Ecol. Manag. SGEM 2017, 17, 195-202. [CrossRef]

7. Lokshin, E.P.; Kalinnikov, V.T.; Tareeva, O.A. The removal of rare-earth elements from Khibini apatite concentrate conversion products, notably middling products and technogenic wastes. Tcvetnye Metally 2012, 3, 75-80.

8. Voigt, W. Chemistry of salts in aqueous solutions: Applications, experiments, and theory. Pure Appl. Chem. 2011, 83, 1015-1030. [CrossRef]

9. Medyanik, N.L.; Chanturia, V.A.; Shadrunova, I.V. Quantum-chemical method for selection of a collecting agent to recover zinc and copper (II) cation sin flotation of mine waste waters. J. Min. Sci. 2012, 48, 167-176. [CrossRef]

10. Ramírez-Serrano, B.; Coello-Velazquez, A.L.; Bernardo, A.; Afif, E.; Menendez-Aguado, J.M. Recovery of copper-ion by flotation with potassium amylxanthate. Rev. Metal. 2012, 48, 254-263.

11. Kazanskaya, L.F.; Smirnova, O.M.; Palomo, Á.; Pidal, I.M.; Romana, M. Supersulfated cement applied to produce lightweight concrete. Materials 2021, 14, 403. [CrossRef]

12. Romashev, A.; He, D.; Aleksandrova, T.; Nikolaeva, N. Technological typomorphic associations in caustobiolithes and methods of their extraction. Metals 2021, 11, 121. [CrossRef]

13. Bazhin, V.Y.; Aleksandrova, T.A.; Kotova, E.L.; Suslov, A.P. A modern view of anomalies in the metal groups of the periodic system of D.I. Mendeleev. J. Min. Inst. 2019, 239, 520-527. [CrossRef]

14. Kurdiumov, V.R.; Timofeev, K.L.; Maltsev, G.I.; Lebed, A.B. Sorption of nickel (II) and manganese (II) ions from aqueous solutions. J. Min. Inst. 2020, 242, 209-217. [CrossRef]

15. Storozhenko, D.; Dryuchko, O.; Jesionowski, T.; Ivanytska, I. Some Physicochemical Aspects of the Preparatory Stages in the Formation of Self-cleaning Photocatalytic Active Coatings for Building Construction Materials. Lect. Notes Civ. Eng. 2020, 73, 285-301. [CrossRef]

16. Nikolaev, A.I.; Krivovichev, S.V. Kola Peninsula in solving problems of national arctic materials science. IOP Conf. Ser. Mater. Sci. Eng. 2019, 696, 012019. [CrossRef]

17. Sebba, F. Ion flotation. Metallurgiya 1965, 17, 1062-1063. [CrossRef]

18. Karger, B.L.; Devivo, D.G. General survey of adsorptive bubble separation processes. Sep. Sci. Technol. 1968, 3, 393-424. [CrossRef]

19. Lobacheva, O.; Dzhevaga, N. Rare-earth elements recovery on the example of Europium (III) from lean technogenic raw materials. J. Ecol. Eng. 2017, 18, 122-126. [CrossRef]

20. Savin, S.B. Arsenazo III. M: Atomizdat. Publ. 1966, 256.

21. Timofeev, S.V.; Materova, V.A.; Arkhangelskiy, L.K. Electrode behaviour of anion-selective membranes. Vestn. LGU Phys. Chem. Ser. 1978, 16, 139-141.

22. Hoseinian, F.S.; Rezai, B.; Kowsari, E.; Chinnappan, A.; Ramakrishna, S. Synthesis and characterization of a novel nanocollector for the removal of nickel ions from synthetic wastewater using ion flotation. Sep. Purif. Technol. 2020, 240, 116639. [CrossRef]

23. Grieves, R.B.; Charewicz, W.R. Ion and colloid flotation of Ni, Co and Pt. Sep. Sci. 1975, 10, 77-92.

24. Voronin, N.N.; Demidov, V.V.; Cherkasov, A.V.; Antonova, I.P. Froth solvent sublation of heavy metals from solutions. Zhurnal Prikladnoi Khimii 1992, 65, 2005-2012.

25. Alves, R.C.; Nascimento, M.; Paulino, J.F.; Afonso, J.C. Selection of a hydrometallurgical process for rare earths extraction from a Brazilian monazite. Hydrometallurgy 2021, 200, 105556. [CrossRef]

26. Valsaraj, K.T.; Thoma, G.J.; Thibodeaux, L.J. Nonfoaming adsorptive bubble separation processes. Sep. Technol. 1991, 1, 234-244. [CrossRef]

27. Bryson, G.B.; Valsaraj, K.T. Solvent sublation for waste minimization in process water stream-A pilot scale study. J. Hazard. Mater. 2001, 82, 65-75. [CrossRef]

28. Lu, Y.; Zhu, X. Solvent sublation: Theory and application. Sep. Purif. Method. 2001, 30, 157-189. [CrossRef]

29. Chang, L.; Cao, Y.; Fan, G.; Li, C.; Peng, W. A review of the applications of ion floatation: Wastewater treatment, mineral beneficiation and hydrometallurgy. RSC Adv. 2019, 9, 20226-20239. [CrossRef]

30. Singh, D.K.; Singh, H.; Mathur, J.N. ElsevierExtraction of rare earths and yttrium with high molecular weight carboxylic acids. Hydrometallurgy 2006, 81, 174-181. [CrossRef]

31. Mikhailichenko, A.I. Rare-earth metals. M: Metallurgy 1987, 232.

32. Lidin, R.A.; Andreeva, A.A.; Molochko, A.V. Handbook. Constants of Inorganic Substances; Dvora Publ: Moscow, Russia, 1995.

33. Outo Kumpu Research OY; HSC Chemistry: Moscow, Russia, 2006; version 4.1.

34. Ravdel., A.A.; Ponomareva, A.M. Quick Reference to Physical and Chemical Quantities, 10th ed.; Ivan Fedorov: St. Petersburg, FL, USA, 2003.

35. Dzhevaga, N.V.; Lobacheva, O.L. Analysis of the mixture of rare earth elements by atomic spectroscopy. J. Phys. Conf. Ser. 2019, 1384, 012008. [CrossRef]

36. Gu, X.; Tan, H.; He, X.; Smirnova, O.; Zhang, J.; Luo, Z. Utilization of Carbide Slag by Wet Grinding as an Accelerator in Calcium Sulfoaluminate Cement. Materials 2020, 13, 4526. [CrossRef] [PubMed]

37. Artykova, A.V.; Melamud, V.S.; Boduen, A.Y.; Bulaev, A.G. Possibility of environment-friendly hydrometallurgical treatment of copper-zinc concentrate containing arsenic. IOP Conf. Ser. Earth Environ. Sci. 2021, 666, 032062. [CrossRef] 
38. Tatiana, L.; Igor, F.; Lutskiy, D. Investigation of the effect of the halide ion adding on extraction of rare earth ions from nitrate media applying naphthenic acid. ARPN J. Eng. App. Sci. 2020, 15, 2129-2134.

39. Battsengel, A.; Batnasan, A.; Narankhuu, A.; Haga, K.; Watanabe, Y.; Shibayama, A. Recovery of light and heavy rare earth elements from apatite ore using sulphuric acid leaching, solvent extraction and precipitation. Hydrometallurgy 2018, 179, 100-109. [CrossRef]

40. Cen, P.; Tyumentsev, M.S.; Spahiu, K.; Foreman, M. Metal extraction from a deep eutectic solvent, an insight into activities. Phys. Chem. Chem. Phys. 2020, 22, 11012-11024. [CrossRef]

41. Chelgani, S.C.; Rudolph, M.; Leistner, T.; Gutzmer, J.; Peuker, U.A. A review of rare earth minerals flotation: Monazite and xenotime. Int. J. Min. Sci. Technol. 2015, 25, 877-883. [CrossRef] 